
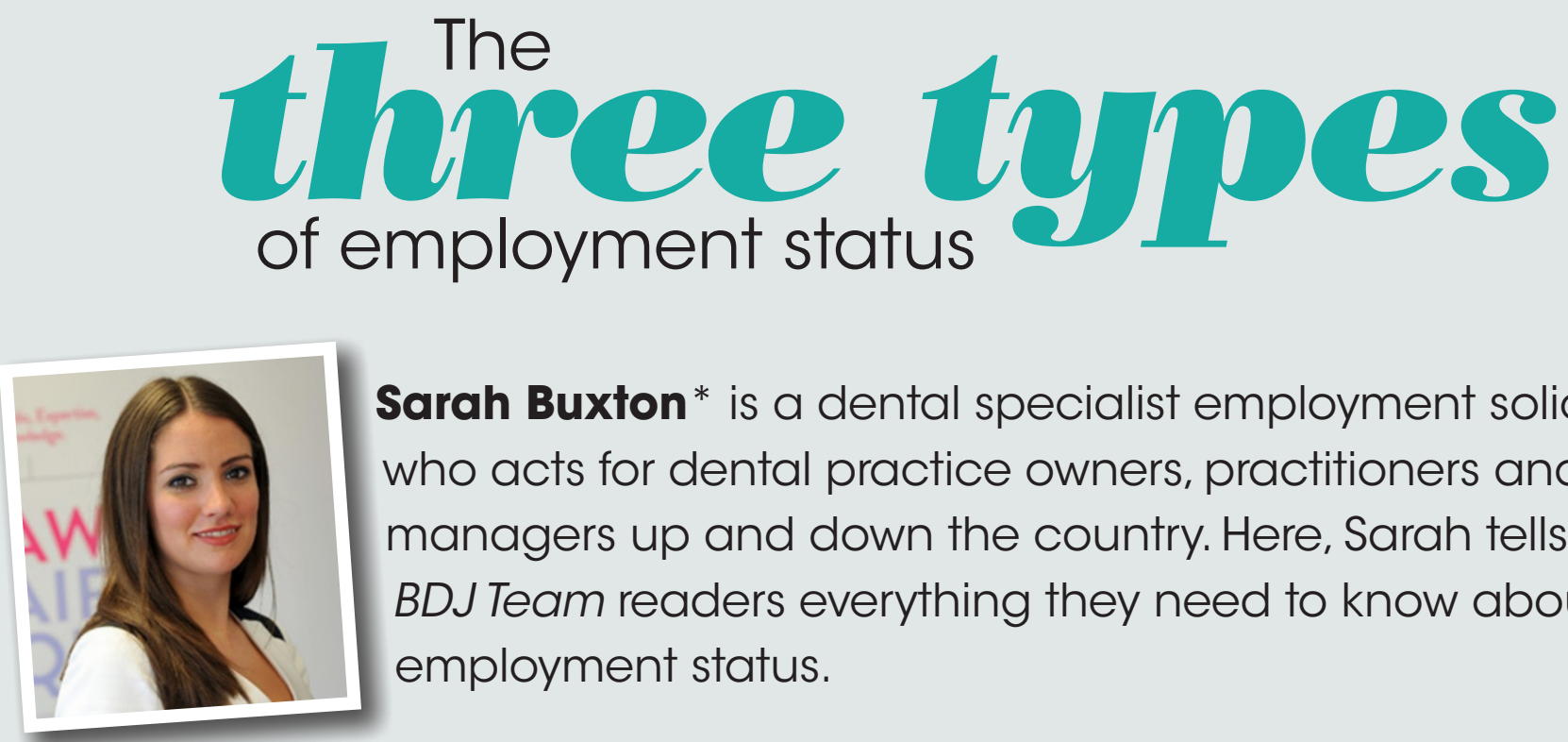

Sarah Buxton* is a dental specialist employment solicitor who acts for dental practice owners, practitioners and managers up and down the country. Here, Sarah tells BDJ Team readers everything they need to know about employment status.

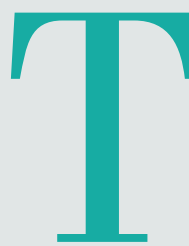

here are three types of employment status: employee, worker and self-employed. The three are often not in practice used correctly and the difference is not always known.

\section{Employee status}

An employee is an individual who has entered into or works (or worked) under the terms of a contract of employment. The contract can be expressly agreed (in writing or orally) or implied by the nature of the relationship. Within a dental practice these tend to be the practice manager, dental nurses, or cleaner. To have employee status:

- An individual must be obliged to do the work personally (rather than being able to send a substitute/locum)

- The employer needs to be obliged to provide the work and the employee is obliged to accept the work

- The employer needs to have some control over the way the employee carries out work.
Worker status

Worker status is sometimes seen as a 'half-way house' between employee and self-employed status. Workers are entitled to fewer statutory rights than employees, but do have some key legal rights, including:

- Protection from discrimination

- Protection against unlawful deduction from wages

- Entitlement to the national minimum wage.

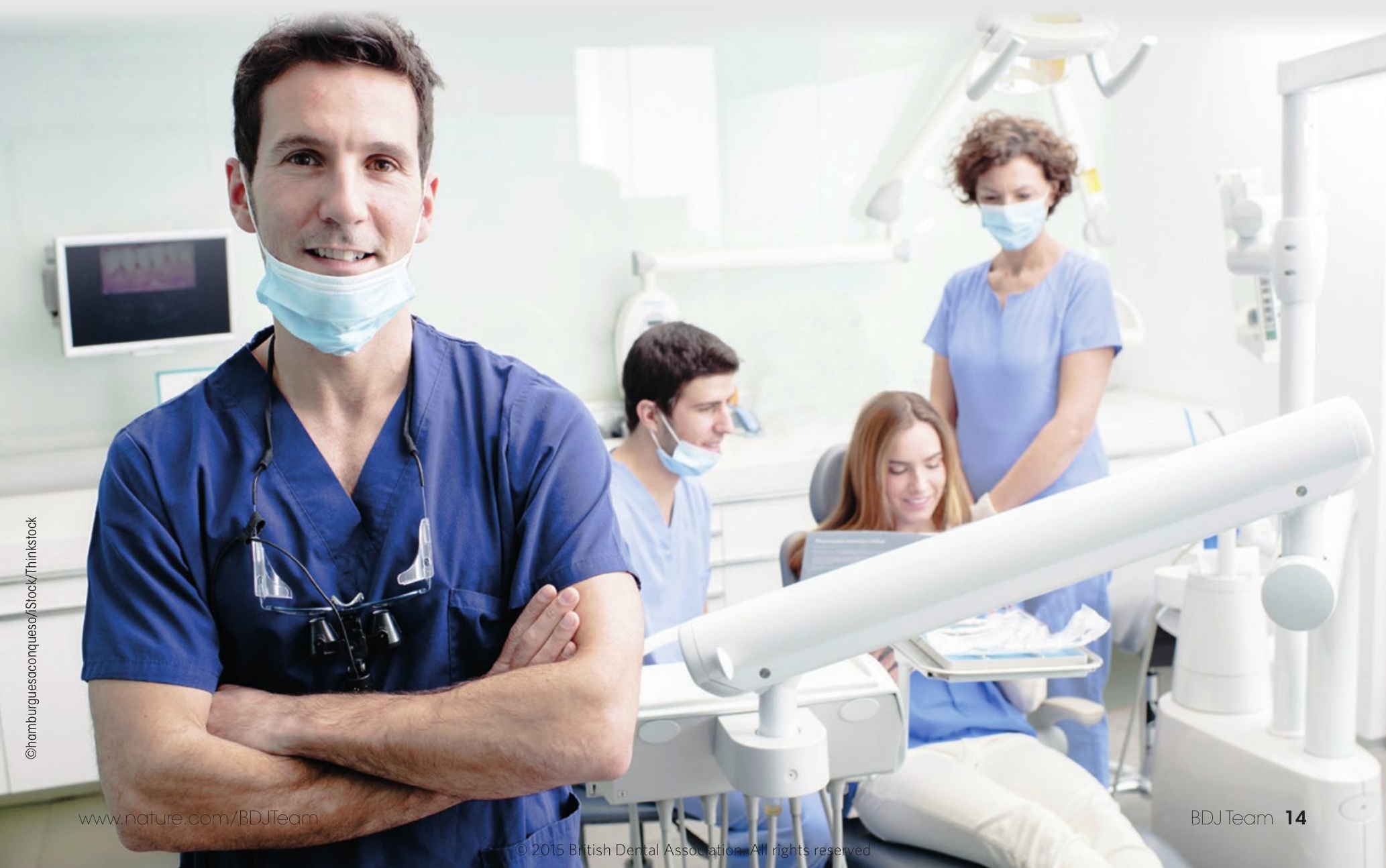


'AN EMPLOYER MUST TAKE OUT EMPLOYER'S

LIABILITY INSURANCE TO COVER THE RISK OF

\section{EMPLOYEES INJURING THEMSELVES AT WORK'}

\section{Self-employed status}

The self-employed enjoy no statutory employment rights (although they may be protected by discrimination law). Selfemployed persons within a dental practice generally include the dental associates, and more often than not, the hygienists and therapists. To be truly self-employed the Courts and HMRC will consider a number of factors:

WRITTEN AGREEMENT - Without a written agreement in place, it is likely that an Employment Tribunal will decide that an individual is an employee. For the individual, the plus side to being an employee means that they can benefit from various protections contained in the employment legislation such as the right not to be unfairly dismissed. This means that if an individual has worked at the same practice for more than two years and they are served notice to terminate their services, they may have a claim for unfair dismissal for which you can currently be awarded up to $£ 74,200$ in compensation. This course of action is not open to selfemployed staff.

CONTROL - A self-employed person should be able to determine when and how they work, this includes the days, hours, and holiday entitlements.

MUTUAL OBLIGATIONS - A selfemployed individual shouldn't be obliged to accept the work which is offered and the dental practice should not be under any obligation to offer work on a regular basis.

PERSONAL SERVICE - There should be no obligation for the services to be carried out personally and there should always be the right to appoint a locum.

EXCLUSIVITY - Associates and hygienists/ therapists should have flexibility as to where they can work and should be able to work at more than one practice.

PAY AND BENEFITS - With regards to payment, the most concerning factor which is often used in practice is when hygienists/ therapists are paid an hourly rate and can often be paid, even when they are not attending any patients. Most self-employed individuals should be paid a percentage of the work they do and hence the payment can be variable. Further, they should not be participating in benefit schemes and should not be paid overtime.
INTEGRATION - A self-employed individual should not be integrated into the dental practice. They should not perform similar services to those performed by employees. For those practices where there is a self-employed hygienist and, at the same practice there are employed hygienists, it is more than likely that the self-employed hygienist will also be classed as employed and therefore practices which are run in this way, are at high risk of there being a claim by HMRC and/or at the Employment Tribunal.

FACILITIES AND EQUIPMENT - A selfemployed person should provide their own equipment and materials in order to perform the services.

FINANCIAL RISK - A self-employed person should be personally responsible for any losses arising from their work. The self-employed person should be required to correct any unsatisfactory work in their own time and at their own expense.

TAXATION - All self-employed individuals should be responsible for payment of their own income tax and National Insurance Contributions (NICs). Furthermore, there should always be a tax indemnity clause within the agreement, so that if HMRC ever decided that the 'self-employed' person was really in practice and an employee and therefore the practice owner had to pay back any tax, NICs including penalties, this payment can in turn be passed to the 'self-employed' individual.

\section{What is the significance of the distinction? \\ Legal protections}

Some core legal protections only apply to employees, for example the right:

- Not to be unfairly dismissed

- To receive a statutory redundancy payment.

\section{Health and safety}

Employers owe employees statutory health and safety protection. Self-employed individuals may not be covered under these duties, although they will be covered under an employer's occupier's liability.

\section{Sales/Purchasers}

Only employees will be automatically transferred to any purchaser of the employer's business.
Tax

An employer is responsible for deducting tax and national insurance at source (PAYE) from the salary paid to employees. Selfemployed individuals are responsible for paying their own tax and national insurance under self-assessment.

\section{Insurance}

An employer must take out employer's liability insurance to cover the risk of employees injuring themselves at work. Selfemployed contractors are unlikely to be covered by this type of insurance.

\section{Liability}

An employer is liable for acts done by an employee in the course of their employment. This type of liability is unlikely to extend to self-employed persons.

\section{Legal status of volunteers}

The legal status of volunteers is not clear cut, as there is a vast range of different types of relationships, from the purely voluntary to those that are clearly contractual and those in between, which are difficult to define. This ambiguity makes it difficult for organisations taking on volunteers to appreciate any legal obligations that they may owe them.

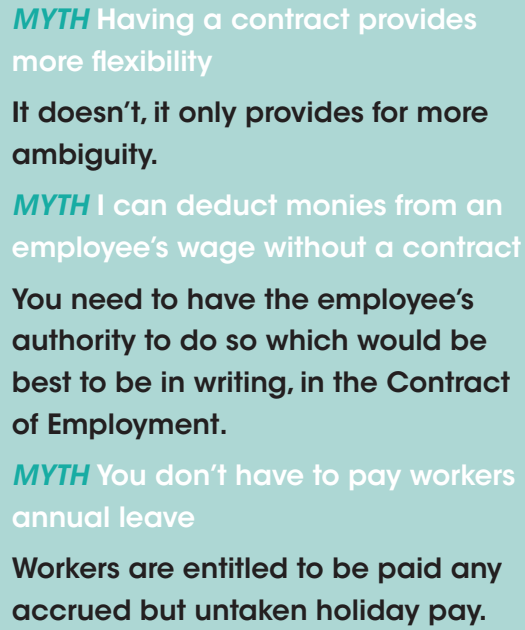

It doesn't, it only provides for more ambiguity.

MYTH

You need to have the employee's authority to do so which would be best to be in writing, in the Contract of Employment.

MYTH You don't have to pay workers

Workers are entitled to be paid any accrued but untaken holiday pay.

*Sarah has a number of years' experience in this specialist field and works in the Dental Team at LCF Law which offers an array of services including buying and selling practices, expense share, partnership and shareholders agreements, incorporations, employment \& $H R$, associate agreements, NHS disputes and regulatory issues.

Please contact 01132010407 or sbuxton@lcf. co.uk for further information.

bdjteam2015124 